\title{
Functional and Chemical Calibrates of Ceramic Cup Water Samplers in Forest Soils
}

\author{
I. Menéndez, ${ }^{1, *}$ J. F. Gallardo, ${ }^{2}$ and M. A. Vicente ${ }^{2}$ \\ 'Departamento de Fisica, Campus Universitario Tafira Baja, Las Palmas \\ de Gran Canaria, Spain \\ ${ }^{2}$ C.S.I.C., Salamanca, Spain
}

\begin{abstract}
A study was conducted to assess the properties of a tension porous-ceramic cup soil-solution sampler and its usefulness in extracting soil solutions in selected forest soils (haplic Umbrisols) at "Sierra De Gata" Mountains, CWSpain. The main characteristics of the sampler evaluated were hydraulic conductivity, the time required to obtain the soil-water sample, and the volume of water uptake for optimum calibration prior to analysis of the chemical composition of the soil water solution. Hydraulic conductivity values were not substantial'y modified during the sampling (two hydrologic cycles). The time required to obtain the samples was relatively short (mean value $2 \mathrm{~h}$ ) and the sphere of sampling influence was small (radii ranging from 6 to $15 \mathrm{~cm}$ ), both depending on the size of the sampler. The chemical analyses obtained after calibrating the ceramic cup sampler pointed to: a) an effect of light adsorption by the ceramic cup, involving $\mathrm{PO}_{4}{ }^{3-}, \mathrm{DOC}$, major and minor cations $\left(\mathrm{Na}^{+}, \mathrm{K}^{+}, \mathrm{Ca}^{2+}, \mathrm{Mg}^{2+}, \mathrm{Fe}^{3+}, \mathrm{Al}^{3+}, \mathrm{Mn}^{2+}\right.$, and $\mathrm{Zn}^{2+}$ ),
\end{abstract}

*Correspondence: I. Menéndez, Departamento de Fisica, Campus Universitario Tafira Baja, Las Palmas de Gran Canaria 35017, Spain; E-mail: imenendez@dfis.ulpgc.es.

1153

DOI: $10.1081 /$ CSS-120019116

Copyright (C) 2003 by Marcel Dekker, Inc.
$0010-3624$ (Print); 1532-2416 (Online) www.dekker.com 
and $\mathrm{SO}_{4}{ }^{2-}$ and $\mathrm{NO}_{3}{ }^{-}$anions; b) a release of $\mathrm{H}_{4} \mathrm{SiO}_{4}$; and c) no clear (rend for $\mathrm{Cl}^{-}$. The $\mathrm{Cu}^{2+}$ values oblained between a blank soil solution and those obtained after passage through the ceramic cup were not correlated. Relatively low $\mathrm{pH}$ values (the $\mathrm{pH}$ of these acid forest soils is $5.1-6.2$ ) favor the adsorption of anions and DOC, the latter also increasing the exchange capacity and cation adsorption of the cup. The results point to a generalized tendency of the ceramic cup to adsorb DOC, cations and anions (with the exception of chlorides), $\mathrm{H}_{4} \mathrm{SiO}_{4}$, by contrast, being released.

Key Words: Ceramic cup water samplers; Chemical calibrate; Forest soils; Mediterranean ccosystem; Bioelements.

\section{INTRODUCTION}

Soil water composition is the result of a dynamic equilibrium between environmental factors and specific physical and chemical soil properties, organic and mineral soil components; water fluxes, etc.

A large variety of soil water extraction techniques is available: pressing, ${ }^{[1]}$ centrifugation, ${ }^{[2,3]}$ displacement, ${ }^{[4]}$ tension ceramic-cup samplers, ${ }^{[5,6]}$ and free-tension lysimeters. ${ }^{[7,8]}$ In the present work, tension ceramic-cup samplers were used in order to obtain matricial waters in acid soil forests, ${ }^{[9,10]}$ with a constant water input, during the hydrological cycle. ${ }^{[11]}$

Ceramic-cup tension samplers permit the extraction of matricial water because an internal negative tension is applied that is higher than the tension at which the matricial water is retained by the soil.

The aim of the present work was to assess the influence of the nature of the ceramic-cup on the characteristics of the soil-solution samples, such as hydraulic conductivity, suction strength applied at both the beginning and the end of the sampling, the time required to obtain samples of matricial water, solution volume, and the viability of the chemical calibrations relating $\mathrm{pH}$, electric conductivity, and dissolved organic carbon (DOC), cations $\left(\mathrm{Na}^{+}, \mathrm{K}^{+}\right.$, $\mathrm{Ca}^{2+}, \mathrm{Mg}^{2+}, \mathrm{Fe}^{3+}, \mathrm{Al}^{3+}, \mathrm{Mn}^{2+}$, and $\left.\mathrm{Zn}^{2+}\right)$, anions $\left(\mathrm{Cl}^{-}, \mathrm{NO}_{3}{ }^{-}, \mathrm{PO}_{4}{ }^{3-}\right.$ and $\left.\mathrm{SO}_{4}{ }^{2-}\right)$, and silica $\left(\mathrm{H}_{4} \mathrm{SiO}_{4}\right)$ concentrations in the matricial water.

\section{MATERIALS AND METHODS}

\section{Study Site}

This study was carried out in selected Quercus pyrencica and Castanea sativa deciduous forests, located in the "Sierra de Gata" $\left(40^{\circ} 2^{\prime} 40^{\prime \prime} \mathrm{N} ; 3^{\circ} 0^{\prime} 50^{\prime \prime}\right.$ 
W; C-W Spain). According to Emberger's climogram, the climatc is humid Mediteranean (Table 1), with a clear inversion between the rainfall and temperature curves, most of the rainfall being concentrated in the cold part of the year and drought coinciding mostly with the warm season and the vegetative growth period. ${ }^{|2|}$ There is a decreasing NE-SW pluviometric transept (from 1.580 to $870 \mathrm{~mm}^{-1}{ }^{-1}$ ). ${ }^{[131}$ Along that transept, mean annual potential evapotranspiration is between 589 and $725 \mathrm{~mm} \mathrm{a}^{-1}$.

The lithology of the area studied consists of greywackes and shales, forming the Palaeozoic basement-affected by regional and contact metamorphism-and two-mica granite intrusions. ${ }^{[|4|}$ This basement has been subject to a weathering process, producing kaolinite enrichment and losses of silica and bases; a second weathering process involved profile silicification and the transtormation of kaolinites in aluminum-rich smectites. ${ }^{[15,16]}$

The soils studied here are acid bccause they are derived from an acid substrate. ${ }^{1171}$ The soil is poor-10-moderately developed (from 0.1 to $0.6 \mathrm{~m}$ ) in the unweathered rock substrate and fairly well developed (from 0.6 to $1.2 \mathrm{~m}$ ) in the previously weathered rock substrate. Moderate temperatures and a relatively high pluviometry favor soil organic-matter accumulation. Iron ( $\mathrm{Fe}$ ) oxides, as a valuable index of the intensity of the pedological process, are released to an appreciable extent from the mincral structure and hence sesquioxides are present in soils; brtmification is the predominant pedological process in these profiles. ${ }^{[18 \mid}$ The soils studied soils were haplic Umbrisols ${ }^{|19|}$ on granite and greywake substrales. The particular profile studied is of the $A h B w C$ type, with a thickness of 0.5 to $0.9 \mathrm{~m}$; the $A$ horizon is umbric, with a good structure and dark color; the $B$ horizon is cambic $(B w)$ with light greenbrown color owing to a noteworthy degree of weathering. Gleyic Umbrisols are developed on granite sites, with poor internal drainage.

\section{Characteristics of the Ceramic-Cup Sampler}

Commercially available ceramic-cup tension samplers (Soilmoisture Equipment, Santa Barbara, CA, USA; 1900 model) were used, following an original design by Wagner. ${ }^{|S|}$ Diflerent tube lengths were employed $(0.15,0.3$, $0.6,0.9$, and $1.1 \mathrm{~m}$, approximately). The negative pressure value of the ceramic cup was $-0.2 \mathrm{MPa}$ (pore size equivalent $=1.44 \mu \mathrm{m}$ ). The negative pressure programmed was $-80 \mathrm{kPa}$, although in the field a range between $-75 \pm 5 \mathrm{kPa}$ was obtained (Table 2 ). 
Table 1. General characteristics of the soil profiles studied.

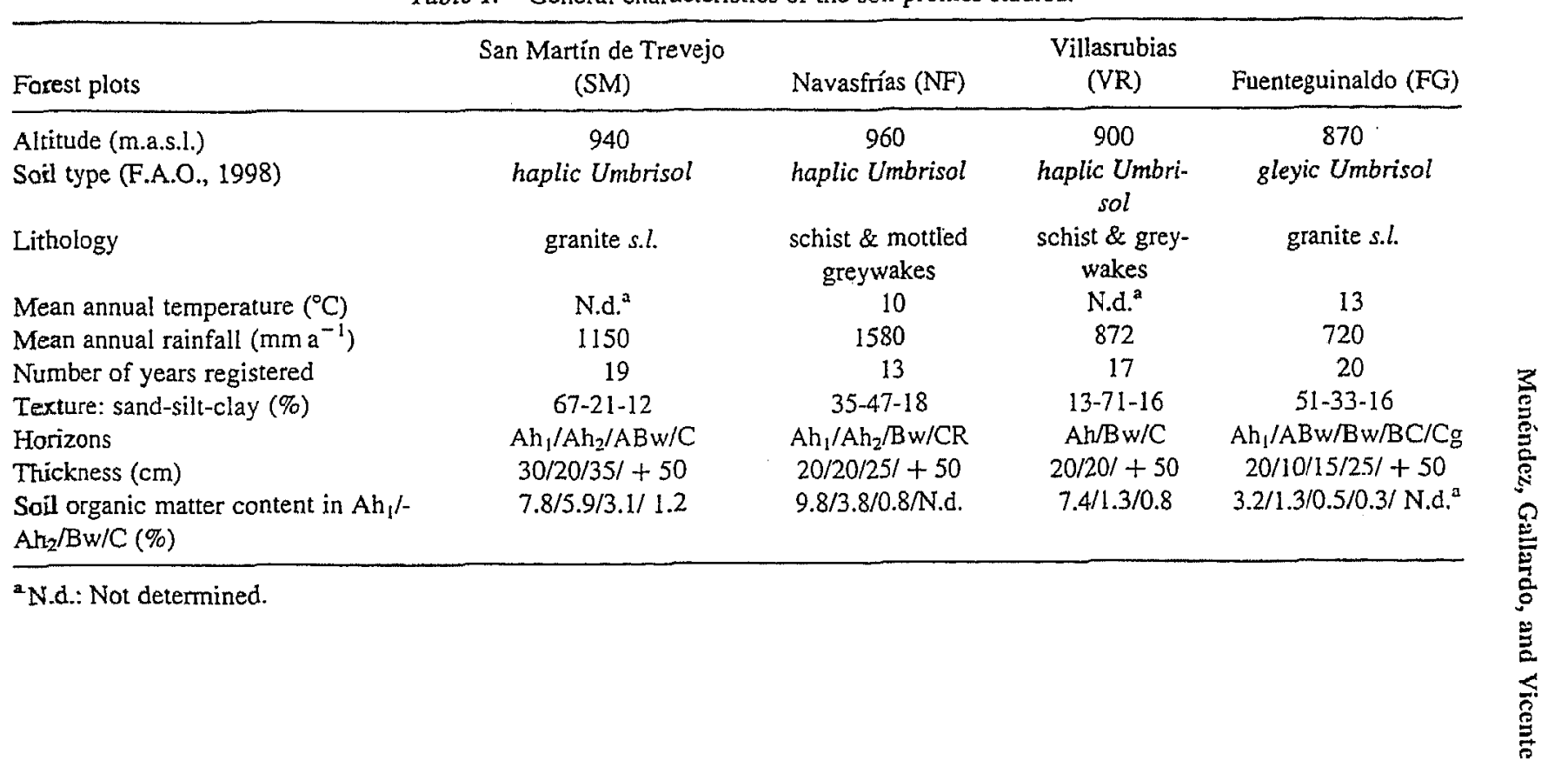


Table 2. Mean suction range obtained during the uptake of soil water by suction cups, sample volume, hydraulic conductivity values of ceramic cups, filling time, and flow value of the samplers.

\begin{tabular}{lccccccccc}
\hline $\begin{array}{l}\text { Study } \\
\text { plot }\end{array}$ & $\begin{array}{c}\text { Depth } \\
(\mathrm{m})\end{array}$ & $\begin{array}{c}\text { Suction range } \\
(\mathrm{kPa})\end{array}$ & S.d $^{\mathrm{a}}(\%)$ & $\begin{array}{c}\text { Sample } \\
\text { volume }(\mathrm{L})\end{array}$ & S.d $^{\mathrm{a}}(\%)$ & $\begin{array}{c}\text { Hydraulic } \\
\text { conductivity } \\
\left(\mathrm{m} \mathrm{s}^{-1}\right)\end{array}$ & S.d $^{\mathrm{a}}(\%)$ & $\begin{array}{c}\text { Filling time } \\
(\text { seconds })\end{array}$ & $\begin{array}{c}\text { Flaw } \\
\left(\mathrm{mL} \mathrm{h}^{-1}\right)\end{array}$ \\
\hline SM & 0.3 & 55 & 4 & 0.38 & 21 & $3.6 * 10^{-9}$ & 30 & 192 & 239 \\
SM & 0.6 & 56 & 4 & 0.73 & 35 & $2.9 * 10^{-9}$ & 56 & 456 & 191 \\
SM & 0.9 & 53 & 3 & 1.04 & 50 & $3.1 * 10^{-9}$ & 30 & 612 & 205 \\
SM & 1.1 & 43 & 3 & 1.26 & 66 & $4.7 * 10^{-9}$ & 45 & 480 & 315 \\
NF & 0.2 & 37 & 4 & 0.15 & 14 & $1.4 * 10^{-9}$ & 40 & 192 & 94 \\
NF & 0.3 & 19 & 5 & 0.09 & 19 & $3.1 * 10^{-9}$ & 56 & 120 & 188 \\
NF & 0.6 & 49 & 3 & 0.68 & 30 & $5.0 * 10^{-9}$ & 43 & 252 & 326 \\
NF & 0.9 & 19 & 3 & 0.37 & 43 & $4.2 * 10^{-9}$ & 26 & 156 & 282 \\
VR & 0.2 & 27 & 4 & 0.12 & 12 & $1.3 * 10^{-9}$ & 24 & 36 & 393 \\
VR & 0.3 & 27 & 4 & 0.23 & 26 & $1.5 * 10^{-9}$ & 35 & 276 & 100 \\
VR & 0.6 & 12 & 3 & 0.16 & 21 & $1.1 * 10^{-9}$ & 59 & 264 & 74 \\
FG & 0.2 & 58 & 4 & 0.21 & 14 & $2.0 * 10^{-9}$ & 43 & 192 & 128 \\
FG & 0.3 & 51 & 4 & 0.36 & 23 & $2.6 * 10^{-9}$ & 41 & 252 & 172 \\
FG & 0.6 & 34 & 4 & 0.51 & 44 & $6.0 * 10^{-9}$ & 49 & 156 & 389 \\
FG & 0.9 & 25 & 4 & 0.56 & 58 & $5.0 * 10^{-9}$ & 27 & 204 & 327 \\
FG & 1.1 & 30 & 4 & 0.77 & 77 & $7.0 * 10^{-9}$ & 44 & 204 & 454 \\
Mean & 0.6 & 37 & 4 & 0.48 & 35 & $3.6 * 10^{-9}$ & 41 & 256 & 228 \\
\hline
\end{tabular}

${ }^{a}$ S.d. = standard deviation of the value. 
The hydraulic conductivity of the ceramic cups was defined by ${ }^{[20]}$.

$$
\mathrm{K}=(\mathrm{Q} * \mathrm{D}) /(\mathrm{A} * \Delta \mathrm{h} * \Delta \mathrm{t})
$$

where: $\mathrm{K}$ is hydraulic conductivity $\left(\mathrm{cm} \mathrm{s}^{-1}\right) ; \mathrm{Q}$ is water volume $\left(\mathrm{cm}^{3}\right) ; \mathrm{D}$ is cup thickness $(0.24 \mathrm{~cm}) ; A$ is the internal surface area of the cup $\left(68 \mathrm{~cm}^{2}\right) ; \Delta \mathrm{h}$ is the hydraulic gradient of the sampling tube, subjected to progressive suction, which decreases over time from -75 to $-10 \mathrm{kPa}$; and $\Delta \mathrm{t}$ is incremental flux time (in seconds).

The ceramic-cup samplers were installed on the different horizons in selected study plots (Table 1), as a function of the thickness of their soil horizon, type, and the lithology of the soil profiles: 5 lysimeters were installed at the Fuenteguinaldo plot (FG, with $0.15,0.3,0.6,0.9$, and $1.1 \mathrm{~m}$ depth), 4 at the San Martín de Trevejo (SM, with 0.2,0.6,0.9, and $1.1 \mathrm{~m}$ depth) and at the Navasfrias plots (NF, with $0.15,0.3,0.6$, and $0.9 \mathrm{~m}$ depth), respectively, and 3 at the Villasrubias plot (VR, with $0.15,0.3$, and $0.6 \mathrm{~m}$ depth).

Prior to their installation, the ceramic-cup was rinsed with deionized water, applying suction three times. Several authors ${ }^{[10,21-24]}$ have suggested that it is more appropriate to rinse ceramic cups with dituted $\mathrm{HCl}$ or $\mathrm{HNO}_{3}{ }^{[25]}$ Like other authors, ${ }^{[26-281}$ however, here we decided to rinse the ceramic cups only with deionized water, because acid rinsing could increase phosphate sorption.

The ceramic-cup samplers were saturated in water before installation. In order to ensure intimate contact between the ceramic cup and the soil, a narrow hole was made in the soil with a manual auger. The displaced soil was mixed with deionized water and used to fill the hole between soil and the sampler. A cut funnel was placed over each lysimeter to protect the sampler from percolation.

The period sampled was longer than two hydrologic periods (28 months: from March 1992 to July 1994; the first 5 months were considered a stabilization period) and water samples were collected every $1-2$ weeks.

\section{Chemical Analyses}

Sampling conditions (before chemical analysis) involved ${ }^{[29]}$ the use of PVC recipients, refrigerated conservation $\left(4^{\circ} \mathrm{C}\right)$, and acidification of the samples at $\mathrm{pH}<2$ (with nitric acid) for cation analysis.

The parameters analyzed ${ }^{[30]}$ were $\mathrm{pH}$ (Crison micropH 2002, using an lngold-104053931 electrode) and electrical conductivity (WTW-LF91 electrode), and DOC (TOCA 315A from Beckman); the ions analyzed were $\mathrm{Na}^{+}$and $\mathrm{K}^{+}$(flame emission, Varian $\mathrm{AA}-1475$ ), $\mathrm{Ca}^{2+}$ and $\mathrm{Mg}^{2+}$ (atomic 
absorption spectrometry, AAS, Varian $\mathrm{AA}-1475), \mathrm{Al}^{3+}, \mathrm{Fe}^{3+}, \mathrm{Cu}^{2+}, \mathrm{Mn}^{2+}$, $\mathrm{Zn}^{2+}$, and $\mathrm{H}_{4} \mathrm{SiO}_{4}\left(\mathrm{ICP} 2\right.$, Perkin-Elmer), and $\mathrm{Cl}^{-}, \mathrm{NO}_{3}{ }^{-}, \mathrm{PO}_{4}{ }^{3-}$, and $\mathrm{SO}_{4}{ }^{2-}$ (ion-chromatography Dionex-350).

\section{Chemical Calibrates of Matricial Solution in Ceramic Cup}

At the end of the sampling period, ceramic-cup samplers were calibrated chemically at the laboratory. Each lysimeter was calibrated four times with water obtained from zero-tension lysimeters ${ }^{[3 \mid]}$ at the same depth as the tube samplers; this solution was considered as the blank test solution (BTS). The solution obtained from the sampler was made to pass lhrough the cup (TCS). The parameters calibrated were $\mathrm{pH}$, electrical conductivity, DOC, and the major cations $\left(\mathrm{Na}^{+}, \mathrm{K}^{+}, \mathrm{Ca}^{2+}, \mathrm{Mg}^{2+}, \mathrm{Fe}^{3+}, \mathrm{Al}^{3+}, \mathrm{Mn}^{2+}\right.$, and $\mathrm{Zn}^{2+}$ ), major anions $\left(\mathrm{Cl}^{-}, \mathrm{NO}_{3}{ }^{-}, \mathrm{PO}_{4}{ }^{3-}\right.$ and $\left.\mathrm{SO}_{4}{ }^{2-}\right)$, and silica $\left(\mathrm{H}_{4} \mathrm{SiO}_{4}\right)$ of the soil solution.

Regression equations were obtained to perform an accurate test of the relationship between the zero-tension lysimcter and ceramic cup soil-solution values, and coefficients were deduced by geometric means and standard errors of the values.

\section{RESULTS AND DISCUSSION}

\section{Tension of Sampling Cups During Water Collection}

An initial pressure was applied, will values of $-75 \pm 5 \mathrm{kPa}$, but the water volume obtained differed from sample to sample as a function of sampler length (Table 2), in agreement with previous research.$^{[32,33]}$ Additionally, the concentrations of the soil water sampled were not significantly influenced by the suction applicd. ${ }^{[33 \mid}$ Taking into account that the same tension was applied to all the tubes, the water volume collected was directly related to the internal volume of the sampler tube because in the longer tubes more air is displaced owing to the higher volume of the samplers.

The final tension registered at the moment of sample collection ( $1-2$ weeks) was not zero in the periods when the soil was wet (winter), and in this case samples were available. Even at the beginning of dry periods (spring), when no matricial water could be obtained, some residual tension was present $(-2 \mathrm{a}-4 \mathrm{kPa})$. These results confirm the good closure and effectiveness of the soil-solution samplers. 


\section{Hydraulic Conductivity of Ceramic-Cup Samplers}

Hydraulic conductivity values ranged from 1 to $7 \times 10^{-7} \mathrm{~cm} \mathrm{~s}^{-1}$ (Table 2). These values lie within the range of calibrations provided by the Soilmoisture Company. The highest values of hydraulic conductivity corresponded to the longest tube-samplers. Morrison and Lowery ${ }^{[34]}$ concluded that, when the same initial suction pressure is applied, hydraulic conductivity is directly related to the internal volume of sampler. This trend was also observed here, with the exception of the VR plot (with low and constant values), probably due to the obstruction of ceramic pores by silt, iron oxides (particularly more abundant in this plot), and soil organic matter (Table 1 ).

\section{Sphere of Water Uptake}

The volume of soil affected by water uptake through the ceramic-cup sampler was restricted to a narrow surrounding zone (Table 3). Evidently,

Table 3. Calculations of water catchment radius from ceramic cups at the profiles studied.

\begin{tabular}{lccccc}
\hline Study plot & Depth (m) & $W^{\mathrm{a}}(\%)$ & $\mathrm{V}^{\mathrm{b}}\left(\mathrm{dm}^{3}\right)$ & $\mathrm{Z}^{\mathrm{c}}\left(\mathrm{dm}^{3}\right)$ & $\mathrm{r}^{\mathrm{d}}(\mathrm{cm})$ \\
\hline SM & 0.3 & 9.2 & 0.38 & 4.16 & 11 \\
SM & 0.6 & 9.4 & 0.73 & 7.73 & 14 \\
SM & 0.9 & 8.8 & 1.04 & 11.85 & 16 \\
SM & 1.1 & 8.4 & 1.26 & 14.99 & 17 \\
NF & 0.2 & 9.9 & 0.15 & 1.53 & 8 \\
NF & 0.3 & 11.0 & 0.09 & 0.86 & 7 \\
NF & 0.6 & 9.9 & 0.68 & 6.91 & 13 \\
NF & 0.9 & 7.3 & 0.37 & 5.01 & 12 \\
VR & 0.2 & 11.0 & 0.12 & 1.07 & 7 \\
VR & 0.3 & 12.0 & 0.23 & 1.91 & 9 \\
VR & 0.6 & 10.0 & 0.16 & 1.63 & 8 \\
FG & 0.2 & 7.1 & 0.21 & 2.90 & 10 \\
FG & 0.3 & 8.7 & 0.36 & 4.16 & 11 \\
FG & 0.6 & 7.9 & 0.51 & 6.42 & 13 \\
FG & 0.9 & 6.7 & 0.56 & 8.28 & 14 \\
FG & 1.1 & 7.1 & 0.78 & 10.92 & 15 \\
\hline
\end{tabular}

W: bulk of water at field capacity $(-30$ to $-20 \mathrm{kPa})$.

${ }^{\mathrm{h}} \mathrm{V}$ : soil water content from -30 to $-200 \mathrm{kPa}$.

${ }^{c} Z$ : caption water zone,

"r: radius of soil sphere influence 
extraction of water in this zone modifies the natural flux, ${ }^{[33.35]}$ although this modification is less pronounced if an individual burst of suction is applied instead of continued suction. ${ }^{[36 \mid}$ Under conditions of individual bursts of suction, the zone of water uptake is restricted to the proximity of the ceramic cup. ${ }^{[32]}$

Assuming that the soil is at field capacity, the soil tension varies from -30 to $-200 \mathrm{kPa}$ ( $\mathrm{pF}$ from 2.5 to 3.2 ) and if the water volumes inside the ceramic cup are known the water uplake zone $\left(\mathrm{Z}, \mathrm{dm}^{3}\right)$ can be defined by the relationship (Table 3 ):

$$
\mathbf{Z}=\mathbf{V} * 100 / \mathrm{W}
$$

where $\mathrm{V}$ is the volume of water extracted $\left(\mathrm{dm}^{3}\right)$ and $\mathrm{W}$ is the percentage (in volume) of soil water content at $-200 \mathrm{kPa}$.

The idealized volume of water uptake would consist of a sphere surrounding the ceramic-cup, with a radius varying between 6 and $15 \mathrm{~cm}$ (Table 3 ). Here, the values of the watcr uptake zone were sufficiently small to prevent zone overlapping (Table 1).

\section{Filling Time of Soil-Water Samplers}

From the water volumes sampled during the two hydrologic cycles and the hydraulic conductivity values obtained with formula (I) it was possible to determine the time required for the samplers to fill. The results are summarized in Table 2 and range from 1 to 2 hours.

\section{Soil-Water Extraction Conditions and Soil Water Content}

Three cases of soil-water extraction were defined, as a function of the soil water content. 1) Soil matricial water retained with lower tensions than inside the sampler. In this situation, soil water extraction is possible; this period was from the middle of autumn to the beginning of summer. 2) Soil matricial water retained with tensions similar to inside the sampler. In this situation, the extraction of soil-water is not possible, although no loss of suction pressure in the samplers occurred. This period lasted between one and two weeks during the wet period (at the beginning of autumn) and also at the beginning of the dry period (late spring-early summer). 3) Soil matricial water retained with tensions higher than inside the sampler may reach (and possibly exceed) the bubble point of the ceramic cup $(-200 \mathrm{kPa})$. In this situation (summer), 
soil-water extraction is not possible and only a loss of suction in the samplers was observed (corresponding to the dry months, in the middle of summer).

The water volume values obtained during two hydrological periods ranged between 0.094 and $1.26 \mathrm{~L}(0.15 \mathrm{~m}$ and $1.1 \mathrm{~m}$ sampler depth, respectively). If the soil water content is similar at all the sites and the same initial suction is applied, the internal volume of the sampler will be directly related to the water volume obtained, ${ }^{[35]}$ although not all authors agree with this. ${ }^{[33]}$ Other authors ${ }^{[37]}$ have argued that the volume of the solution recovered decreases with time due to obstruction of the ceramic by colloids and oxides of iron. This was seen at the VR plot.

In the present study of natural forest soils, clear differences were seen in the water volume obtained in both hydrological cycles studied (Table 4). The first hydrological year was dryer $(829 \mathrm{~mm}$ total annual rainfall) than the second one (1.464 mm total annual rainfall) and hence an increase occurred in the volume of the soil-solution in the wet period of the second cycle, atthough a decrease also occurred in the volume of the soil-solution from the first to second cycle in the dry period. The latter was probably due to progressive obstruction of the ceramic of the cup due to the precipitation of colloids and oxides of iron, more pronounced in dry periods. Hysteresis phenomena (stronger soil water retention during dry periods) could be the most important cause of higher volumes in wet periods with respect to dry ones.

\section{Chemical Calibration of Solution Passing Through the Ceramic Cup}

Linear regression equations were obtained to compare the results of the chemical analyses of the water obtained with the zero-tension lysimeter (blank test solution, BTS) and those obtained with the solution passing through the ccramic cup (TCS). From each equation, a concentration correction factor was deduced (Table 5) (using geometric means) and this factor was further applied to the soil water sample analyses (except for $\mathrm{PO}_{4}{ }^{3-}$ and $\mathrm{Cu}^{2+}$, which were below the limit of detection; Table $6 \mathrm{a}, \mathrm{b})$.

The chemical composition of the ceramic cup (constructed with kaolinite, talc, alumina, and other feldspar minerals ${ }^{[20]}$ modifies the composition of the soil solution due to exchange phenomena. Many works have addressed the sorption-leaching capacity of ceramics, ${ }^{[10,24,26,27,38-45]}$ but there is little consensus about the behavior of these ions (Table 7). Some works ${ }^{[43]}$ have shown that the concentrations of $\mathrm{Ca}^{2+}$ and $\mathrm{Mg}^{2+}$ increase when they pass through ceramic cups while other authors ${ }^{[38]}$. have indicated that major cation concentrations remain unaltered under such conditions or that they are 
Table 4. Mean values of volume ol soil water ubtained by suction cups, and percentage of change (from 100\%) in dilferent periods (wol and dry) in the hydrological cycles analysed (l and II).

\begin{tabular}{|c|c|c|c|c|c|c|}
\hline Plot & $\begin{array}{l}\text { Depth } \\
\text { (m) }\end{array}$ & $\begin{array}{l}\text { Volume } \\
\text { (L) Iab }\end{array}$ & $\begin{array}{l}\text { Volumc } \\
\text { (L) } \mathrm{Ib}^{\mathrm{a}}\end{array}$ & $\begin{array}{l}\text { Volume" } \\
\text { (L) Ila" }\end{array}$ & $\begin{array}{l}\text { Volumc } \\
\text { (L) } I \mathrm{~b}^{\mathrm{t}}\end{array}$ & $\begin{array}{c}\text { \% of } \\
\text { change } \mathrm{a}^{\mathrm{r}} / \mathrm{b}^{\mathrm{z}}\end{array}$ \\
\hline \multirow[t]{4}{*}{ SM } & 0.3 & $0.45(3)$ & $0.41(23)$ & $0.44(8)$ & $0.32(56)$ & $98 / 77$ \\
\hline & 0.6 & $0.82(9)$ & $0.79(13)$ & $0.81(10)$ & $0.71(35)$ & $98 / 90$ \\
\hline & 0.9 & $1.22(5)$ & $1.12(13)$ & $1.17(6)$ & $0.91(43)$ & $96 / 81$ \\
\hline & 1.1 & $1.24(39)$ & $1.53(9)$ & $1.48(11)$ & $0.91(58)$ & $119 / 59$ \\
\hline \multirow[t]{4}{*}{$\mathrm{NF}$} & 0.15 & $2.00(39)$ & $0.2 !(40)$ & $0.17(52)$ & $0.11(97)$ & $87 / 51$ \\
\hline & 0.3 & $0.05(34)$ & $0.05(55)$ & $0.09(54)$ & - & $1731-$ \\
\hline & 0.6 & $0.59(39)$ & $0.60(35)$ & $0.80(11)$ & $0.70(29)$ & $135 / 118$ \\
\hline & 0.9 & $0.15(34)$ & $0.2 !(2 !)$ & $0.40(49)$ & $0.16(57)$ & $260 / 77$ \\
\hline \multirow[t]{3}{*}{ VR } & 0.15 & $0.09(71)$ & $0.16(37)$ & $0.14(46)$ & $0.15(50)$ & $152 / 94$ \\
\hline & 0.3 & $0.07(67)$ & $0.21(44)$ & $0.36(39)$ & $0.28(48)$ & $497 / 132$ \\
\hline & 0.6 & $0.09(51)$ & $0.18(52)$ & $0.22(75)$ & $0.15(77)$ & $248 / 85$ \\
\hline \multirow[t]{6}{*}{ FG } & 0.15 & $0.23(29)$ & $0.26(9)$ & $0.25(26)$ & $0.20(52)$ & $108 / 74$ \\
\hline & 0.3 & $0.40(33)$ & $0.44(25)$ & $0.44(19)$ & $0.30(47)$ & $112 / 69$ \\
\hline & 0.6 & $0.59(51)$ & $0.72(21)$ & $0.57(39)$ & $0.32(78)$ & $97 / 45$ \\
\hline & 0.9 & $0.33(55)$ & - & $0.81(41)$ & $0.39(98)$ & $2441-$ \\
\hline & 1.1 & $0.46(95)$ & - & $1.19(34)$ & $0.65(78)$ & $259 /-$ \\
\hline & & & & & Mean & $174 / 81$ \\
\hline
\end{tabular}

${ }^{a}$ Volume: Mean water volume and standard devialion, in brackets.

b Ia: Wet period of lirst hydrological period.

"Ib: Dry period of first hydrological period.

¿IIa: Wel period of second hydrological cycle.

"IIb: Dry period of sccond hydrological cycle.

a: Wet period.

b: Dry period.

adsorbed on passing through ceramic cups. ${ }^{(4)}$ Here, the major cations studied showed a tendency towards ion sorption when they passed through the ceramic cups (Tables 5 and 7).

The minor cations $\mathrm{Fe}^{3+}, \mathrm{Mn}^{2+}, \mathrm{Cu}^{2+}$, and $\mathrm{Zn}^{2+}$ were adsorbed by the ceramic cups (Table 5). Other authors ${ }^{|44|}$ reported the absence of sorption behavior for $\mathrm{Cu}^{2+}$, and $\mathrm{Zn}^{2+}$ at $\mathrm{pH}=4$. In the present study, minor cations showed a tendency to be sorbed by the ceramic cups (Table 7; pH range 5.7-6.9). The metal load influences the effect of $\mathrm{pH}$ on ion sorption, but this is only evident at concentrations much higher than those found in nature..$^{\mid 461}$ Thus, at a moderate metal load of $\mathrm{Zn}^{2+}\left(45 \mathrm{mmolg}^{-1} ; 46\right.$; from 2 to $20 \mathrm{mmol} \mathrm{g}^{-1}$ in our study, figures commonly tound in the soil environment) 
Table 5. Chemical calibration results: regression equations between blank test solution and passage through ceramic solution; regression cocfficient $\left(\mathrm{r}^{2}\right)$; number of data $(n): 64$.

\begin{tabular}{|c|c|c|c|c|c|c|}
\hline \multirow[b]{2}{*}{ Parameler } & \multirow[b]{2}{*}{$\begin{array}{c}\text { Regression } \\
\text { cquation }\end{array}$} & \multirow[b]{2}{*}{$\left(\mathrm{r}^{2}\right)$} & \multicolumn{4}{|c|}{ TCS $^{a}$ values respecting $100 \%$ of $\mathrm{BTS}^{\mathrm{b}}$} \\
\hline & & & $\begin{array}{c}\text { Geomctric } \\
\text { mean }\end{array}$ & $\begin{array}{c}\text { Error } \\
(+1-)\end{array}$ & $\begin{array}{l}\text { Corrected } \\
\text { factor }\end{array}$ & Tendency \\
\hline $\mathrm{H}^{+}$ & $\mathrm{TCS}^{4}=0.60 \mathrm{LBTS}^{3}+2.41$ & 0.566 & 102 & 6 & 0.98 & $L^{2}$ \\
\hline$\alpha^{\mathbf{U}}$ & $\mathrm{TCS}=0.877 \mathrm{BTS}+3.744$ & 0.933 & 92 & 9 & 1.09 & $R^{2}$ \\
\hline $\mathrm{DOC}$ & $\mathrm{TCS}=0.748 \mathrm{BTS}+0.683$ & 0.892 & 84 & 18 & 1.19 & $\mathbf{R}$ \\
\hline $\mathrm{Na}^{+}$ & $\mathrm{TCS}=0.6578 \mathrm{TS}+0.604$ & 0.525 & 93 & 40 & 1.08 & R \\
\hline $\mathrm{K}^{+}$ & $\mathrm{TCS}=0.855 \mathrm{BTS}+0.219$ & 0.899 & 87 & 17 & 1.15 & R \\
\hline $\mathrm{Ca}^{2+}$ & $\mathrm{TCS}=0.783 \mathrm{BTS}+0.12$ & 0.922 & 84 & 21 & 1.19 & $\mathrm{R}$ \\
\hline $\mathrm{Mg}^{2+}$ & $\mathrm{TCS}=0.842 \mathrm{BTS}+0.109$ & 0.784 & $9 !$ & 34 & 1.10 & R \\
\hline $\mathrm{Si}(\mathrm{OH})_{4}$ & $\mathrm{TCS}=0.934 \mathrm{BTS}+0.247$ & 0.936 & 139 & 144 & 0.72 & $\mathrm{~L}^{\prime}$ \\
\hline $\mathrm{Al}^{3+}$ & $\mathrm{TCS}=0.878 \mathrm{BTS}+0.048$ & 0.828 & 90 & 63 & 1.11 & $\mathrm{R}$ \\
\hline $\mathrm{Fe}^{3+}$ & $\mathrm{TCS}=0.407 \mathrm{BTS}+0.014$ & 0.495 & 69 & 40 & 1.45 & $\mathbf{R}$ \\
\hline $\mathrm{Mn}^{2+}$ & $\mathrm{TCS}=0.729 \mathrm{BTS}+0.004$ & 0.932 & 83 & 112 & 1.21 & $\mathrm{R}$ \\
\hline $\mathrm{Zn}^{2+}$ & $\mathrm{TCS}=0.746 \mathrm{BTS}+0.14$ & 0.676 & 69 & 37 & 1.45 & $\mathrm{R}$ \\
\hline $\mathrm{Cu}^{2+}$ & $\mathrm{TCS}=19.49 \mathrm{BTS}+0.005$ & 0.280 & N.d. & N.d. & N.d. & N.d. \\
\hline $\mathrm{Cl}^{-}$ & $\mathrm{TCS}=0.887 \mathrm{BTS}+0.399$ & 0.993 & 101 & 29 & 0.99 & $I^{h}$ \\
\hline $\mathrm{NO}_{3}$ & $\mathrm{TCS}=0.968 \mathrm{BTS}+0.047$ & 0.987 & 88 & 31 & 1.14 & $\mathbf{R}$ \\
\hline $\mathrm{PO}_{4}^{=}$ & $\mathrm{TCS}=0.708 \mathrm{BTS}+0.042$ & 0.473 & 6 & 3 & 16.67 & $\mathrm{R}^{\mathrm{i}}$ \\
\hline $\mathrm{SO}_{4}^{=}$ & $\mathrm{TCS}=0.873 \mathrm{BTS}+0.225$ & 0.094 & 76 & 14 & 1.32 & k \\
\hline
\end{tabular}

"TCS: passage through ceramic solution.

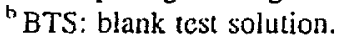

'L: low leachage.

${ }_{\alpha}$ : electric conductivity, in $\mu \mathrm{Scm}^{-2}$.

${ }^{\mathrm{e}} \mathrm{R}$ : low retention.

${ }^{\mathrm{r}} \mathrm{L}$ : leachage.

'N.d.: Not determined.

"I: inalterated.

${ }^{\mathrm{i}} \mathrm{R}$ : retention.

the effect of $\mathrm{pH}$ on metal adsorption is low and this sorption decreases with acidity. A maximum of metal sorption has been reported for $\mathrm{pH}$ values of between 6.3 and $7.0,{ }^{[46]}$ these values being quite similar to those found in our samples.

The values of $\mathrm{Cu}^{+}$before and after passing through the ceramic were not correlated $\left(r^{2}=0.28\right.$; Table 5). Possibly, the low concentrations of this micronutrient (few $\mu \mathrm{gL}^{-1}$ ) could be responsible for this.

The retention (or release) of $\mathrm{Al}^{3+}$ by ceramics depends on the degree of $\mathrm{Al}^{3+}$ saturation of the soils, and is related to the presence of gibbsite in the 


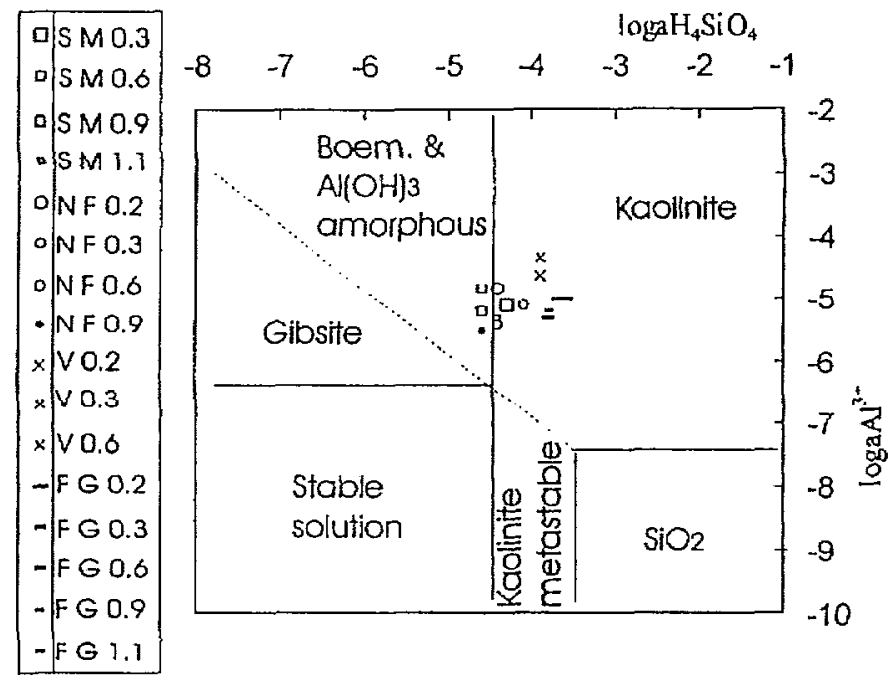

Figzure 1. Mineral stability of soil-solution samples [Al(OH) $)_{3}$-bohemitc-kaoliniteopal system]. ${ }^{|48|}$ Legend: Plot sitc and depths (in m).

soil. ${ }^{[42,47]}$ This is partly in agreement with the present results, because in some-but not all-samples (plots SM 60, SM 90, and NF 90; Fig. 1) the soil-solutions studied were saturated in gibbsitc. Raulund-Rasmussen ${ }^{|45|}$ has remarked that with increasing $\mathrm{pH} \mathrm{Al}^{3+}$ cations are released by the ceramic cup; the interpretation was that protons replace the $\mathrm{Al}^{3+}$ of the ceramic, leading to the formation of amorphous gibbsite close to the ceramic. Thus, in our case a depletion of $\mathrm{Al}^{3+}$ in the solution from the ceramic cup was accompanied by an increase in $\mathrm{H}^{+}$(lower $\mathrm{pH}$ ). Several authors ${ }^{\mid 45.461}$ have related low $\mathrm{pH}$ to the sorption of $\mathrm{Al}^{3+}$.

The $\mathrm{pH}$ value increases when solution passes through the ceramic, duc to elimination of $\mathrm{CO}_{2}$ and other volatiles from the soil solution, ${ }^{149.501}$ although in this work this phenomenon was not observed.

As in other works, ${ }^{|39,43|} \mathrm{H}_{4} \mathrm{SiO}_{4}$ release was detected, although in a highly variable fashion (Table 5). Aluminum (AI) and $\mathrm{Fe}$ oxides and hydroxides are effective sorbents of dissolved silica and owing to the presence of Al-chelating organic acids $\mathrm{Si}$ sorption in soils is decreased. ${ }^{|5|}$ | Soil forest solutions have sufficient DOC (with chelating effects) to permit $\mathrm{H}_{4} \mathrm{SiO}_{4}$ release.

Phosphate sorption has been reported in several works. ${ }^{126.27 .39 .41,441}$ In the

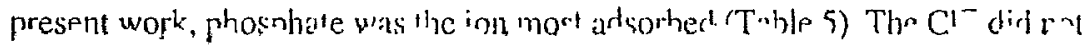


Table 6. Soil water composition (mean and error values) as extracted by ceramic cups collected (at different depths) at the SM and NF plots. A correction factor was applied, except for $\mathrm{PO}_{4}^{2}-$ and $\mathrm{Cu}^{2+}$, registered under detection limit. Values in $\mathrm{mgL}^{-1}$ (except for $\mathrm{X} *$ )

\begin{tabular}{|c|c|c|c|c|c|c|c|c|}
\hline Plot & & & $M$ & & & & & \\
\hline Depth $^{a}$ & 0.3 & 0.6 & 0.9 & 1.1 & 0.2 & 0.3 & 0.6 & 0.9 \\
\hline $\mathrm{pH}$ & $5.9 \pm 0.20$ & $6.0 \pm 0.03$ & $5.7 \pm 0.04$ & $5.8 \pm 0.13$ & $6.6 \pm 0.07$ & $6.8 \pm 0.06$ & $6.3 \pm 0.05$ & $6.6 \pm 0$ \\
\hline$X^{b}$ & $21 \pm 1$ & $20 \pm 1$ & $29 \pm 3$ & $19 \pm 1$ & $26 \pm 2$ & $34 \pm 4$ & $17 \pm 1$ & $13 \pm 1$ \\
\hline DOC & $5.9 \pm 0.5$ & $5.9 \pm 0.5$ & $4.9 \pm 0.4$ & $4.9 \pm 0.4$ & $9.8 \pm 0.9$ & $14.6 \pm 1.2$ & $12.7 \pm 1.9$ & $4.9 \pm 0.4$ \\
\hline $\mathrm{Na}^{+}$ & $2.3 \pm 0.2$ & $1.9 \pm 0.1$ & $2.7 \pm 0.2$ & $2.3 \pm 0.2$ & $1.9 \pm 0.2$ & $2.5 \pm 0.4$ & $1.9 \pm 0.1$ & $2.0 \pm 0.2$ \\
\hline $\mathrm{K}^{+}$ & $1.8 \pm 0.1$ & $1.6 \pm 0.1$ & $1.0 \pm 0.1$ & $1.0 \pm 0.1$ & $1.6 \pm 0.1$ & $1.8 \pm 0.2$ & $0.8 \pm 0.1$ & $0.6 \pm 1.0$ \\
\hline $\mathrm{Ca}^{2+}$ & $0.42 \pm 0.05$ & $0.43 \pm 0.06$ & $0.38 \pm 0.08$ & $0.35 \pm 0.04$ & $0.98 \pm 0.09$ & $1.08 \pm 0.21$ & $0.49 \pm 0.08$ & $0.29 \pm 0.04$ \\
\hline $\mathrm{Mg}^{2+}$ & $0.66 \pm 0.03$ & $0.631 \pm 0.02$ & $0.848 \pm 0.11$ & $0.532 \pm 0.03$ & $0.89 \pm 0.05$ & $0.99 \pm 0.15$ & $0.69 \pm 0.02$ & $0.49 \pm 0.02$ \\
\hline $\mathrm{H}_{4} \mathrm{SiO}_{4}$ & $2.8 \pm 0.35$ & $1.5 \pm 0.21$ & $1.6 \pm 0.30$ & $2.3 \pm 0.58$ & $2.3 \pm 0.4$ & $4.7 \pm 1,1$ & $2.3 \pm 0.6$ & $1.5 \pm 0.2$ \\
\hline $\mathrm{Al}^{3+}$ & $0.22 \pm 0.01$ & $0.15 \pm 0.02$ & $0.41 \pm 0.16$ & $0.15 \pm 0.02$ & $0.39 \pm 0.02$ & $0.22 \pm 0.02$ & $0.11 \pm 0.02$ & $0.08 \pm 0.01$ \\
\hline $\mathrm{Fe}^{3+}$ & $0.09 \pm 0.03$ & $0.10 \pm 0.05$ & $0.21 \pm 0.18$ & $0.07 \pm 0.03$ & $0.09 \pm 0.02$ & $0.10 \pm 0.04$ & $0.05 \pm 0.02$ & $0.03 \pm 0$. \\
\hline $\mathrm{Mn}^{2+}$ & $0,19 \pm 0.07$ & $0,08 \pm 0.03$ & $0,33 \pm 0.11$ & $0,19 \pm 0.07$ & $0,06 \pm 0.03$ & $0,06 \pm 0.03$ & $0,07 \pm 0.02$ & $0,05 \pm 0.0$ \\
\hline $\mathrm{Zn}^{2+}$ & $0.52 \pm 0.08$ & $0.60 \pm 0.11$ & $0.78 \pm 0.17$ & $0.64 \pm 0.13$ & $1.26 \pm 0.27$ & $1.07 \pm 0.24$ & $0.59 \pm 0.12$ & $0.43 \pm 0.05$ \\
\hline $\mathrm{Cl}^{-}$ & $1.7 \pm 0.2$ & $1.6 \pm 0.1$ & $4.3 \pm 0.7$ & $2.3 \pm 0.2$ & $2.3 \pm 0.4$ & $4.1 \pm 1,1$ & $1.6 \pm 0.2$ & $1.1 \pm 0.1$ \\
\hline $\mathrm{NO}_{3}^{-}$ & $0.18 \pm 0.05$ & $0.32 \pm 0.12$ & $0.35 \pm 0.07$ & $0.42 \pm 0.10$ & $0.23 \pm 0.04$ & $0.68 \pm 0.27$ & $0.23 \pm 0.02$ & $0.23 \pm 0.03$ \\
\hline $\mathrm{SO}_{4}^{2-}$ & $3.0 \pm 0.4$ & $3.1 \pm 0.3$ & $2.3 \pm 0.3$ & $1.3 \pm 0.2$ & $2.9 \pm 0.2$ & $5.4 \pm 1.1$ & $2.7 \pm 0.3$ & $1.8 \pm 0.3$ \\
\hline
\end{tabular}

${ }^{2}$ in $\mathrm{m}$.

${ }^{\mathrm{b}}$ electric conductivity, in $\mu \mathrm{S} \mathrm{cm}^{-1}$. 
Table 7. Soil water composition (mean and error values) as extracted by ceramic cups collected (at different depths) at the VR and FG plots. A correction factor was applied, except for $\mathrm{PO}_{4}{ }^{2-}$ and $\mathrm{Cu}^{2+}$, registered under detection limit. Values in $\mathrm{mg} \mathrm{L}^{-1}$ (except for $\mathrm{X}^{*}$ ).

\begin{tabular}{lcccccccc}
\hline Plot & \multicolumn{7}{c}{ VR } & \multicolumn{5}{c}{ FG } \\
\hline Depth $^{2}$ & 0.2 & 0.3 & 0.6 & 0.2 & 0.3 & 0.6 & 0.9 & 1.1 \\
$\mathrm{pH}$ & $6.2 \pm 0.07$ & $5.8 \pm 0.05$ & $5.8 \pm 0.04$ & $6.9 \pm 0.05$ & $6.5 \pm 0.05$ & $6.0 \pm 0.05$ & $5.9 \pm 0.06$ & $5.9 \pm 0.09$ \\
$\mathrm{X}^{6}$ & $26 \pm 3$ & $37 \pm 5$ & $39 \pm 3$ & $58 \pm 6$ & $44 \pm 2$ & $29 \pm 1$ & $37 \pm 1$ & $37 \pm 3$ \\
$\mathrm{DOC}$ & $29 \pm 4$ & $82 \pm 26$ & $78 \pm 19$ & $30.3 \pm 3.2$ & $18.5 \pm 1.5$ & $8.8 \pm 0.8$ & $8.8 \pm 0.8$ & $8.8 \pm 0.8$ \\
$\mathrm{Na}^{+}$ & $2.2 \pm 0.2$ & $2.5 \pm 0.2$ & $2.3 \pm 0.2$ & $2.2 \pm 0.1$ & $2.3 \pm 0.1$ & $2.4 \pm 0.2$ & $2.9 \pm 0.2$ & $2.9 \pm 0.2$ \\
$\mathrm{~K}^{+}$ & $2.2 \pm 0.2$ & $3.1 \pm 0.6$ & $3.3 \pm 0.3$ & $6.1 \pm 0.2$ & $6.6 \pm 0.2$ & $3.0 \pm 0.1$ & $3.5 \pm 0,1$ & $2.3 \pm 0.6$ \\
$\mathrm{Ca}^{2+}$ & $0.42 \pm 0.05$ & $1.08 \pm 0.16$ & $1.15 \pm 0.12$ & $2.06 \pm 0.31$ & $0.69 \pm 0.07$ & $0.29 \pm 0.05$ & $0.39 \pm 0.05$ & $0.29 \pm 0.03$ \\
$\mathrm{Mg}^{2+}$ & $0.74 \pm 0.03$ & $0.97 \pm 0.11$ & $1.13 \pm 0.09$ & $1.87 \pm 0.26$ & $0.99 \pm 0.06$ & $0.59 \pm 0.02$ & $0.69 \pm 0.02$ & $0.99 \pm 0.03$ \\
$\mathrm{H}_{4} \mathrm{SiO}_{4}$ & $4.7 \pm 0.8$ & $5.6 \pm 1.1$ & $4.8 \pm 1.0$ & $15.3 \pm 2.9$ & $10.7 \pm 1.5$ & $9.2 \pm 0.7$ & $9.9 \pm 0.5$ & $9.9 \pm 0.6$ \\
$\mathrm{Al}^{3+}$ & $0.61 \pm 0.06$ & $1.47 \pm 0.22$ & $1.33 \pm 0.19$ & $0.26 \pm 0.02$ & $0.28 \pm 0.02$ & $0.13 \pm 0.01$ & $0.17 \pm 0.02$ & $0.144 \pm 0.01$ \\
$\mathrm{Fe}^{3+}$ & $0.33 \pm 0.17$ & $0.40 \pm 0.15$ & $0.56 \pm 0.24$ & $0.35 \pm 0.15$ & $0.28 \pm 0.12$ & $0.09 \pm 0.04$ & $0.09 \pm 0.03$ & $0.06 \pm 0.02$ \\
$\mathrm{Mn}^{2+}$ & $0.26 \pm 0.10$ & $0.42 \pm 0.16$ & $0.52 \pm 0.16$ & $0.13 \pm 0.05$ & $0.06 \pm 0.02$ & $0.43 \pm 0.15$ & $0.33 \pm 0.12$ & $0.46 \pm 0.17$ \\
$\mathrm{Zn}^{2+}$ & $2.91 \pm 0.72$ & $1.02 \pm 0.21$ & $3.00 \pm 1.03$ & $1.37 \pm 0.03$ & $0.73 \pm 0.15$ & $0.52 \pm 0.06$ & $0.52 \pm 0.06$ & $0.60 \pm 0.07$ \\
$\mathrm{Cl}^{-}$ & $1.3 \pm 0.3$ & $1.2 \pm 0.3$ & $1.2 \pm 0.1$ & $2.8 \pm 0.5$ & $1.6 \pm 0.2$ & $2.5 \pm 0.2$ & $3.3 \pm 0.1$ & $3.7 \pm 0.1$ \\
$\mathrm{NO}_{3}^{-}$ & $0.11 \pm 0.03$ & $0.11 \pm 0.02$ & $0.23 \pm 0.06$ & $2.50 \pm 0.87$ & $2.30 \pm 0.32$ & $0.30 \pm 0.05$ & $0.20 \pm 0.03$ & $0.50 \pm 0.06$ \\
$\mathrm{SO}_{+}^{2-}$ & $2.0 \pm 0.2$ & $2.8 \pm 0.3$ & $2.7 \pm 0.1$ & $4.7 \pm 0.5$ & $5.1 \pm 0.5$ & $3.5 \pm 0.5$ & $4.8 \pm 0.8$ & $4.3 \pm 0.7$ \\
\hline
\end{tabular}

in $\mathrm{m}$

belectric conductivity, in $\mu \mathrm{S} \mathrm{cm}^{-1}$ 
Table 8. Chemical calibration of cup ceramics by other authors and the present work.

\begin{tabular}{|c|c|c|c|c|c|c|c|c|c|c|c|c|c|c|c|}
\hline Authors / ions & $\mathrm{Na}^{+}$ & $\dot{\mathrm{K}}^{+}$ & $\mathrm{Ca}^{2+}$ & $\mathrm{Mg}^{2+}$ & $\mathrm{Al}^{3+}$ & $\mathrm{Fe}^{2+}$ & $\mathrm{Mn}^{2+}$ & $\mathrm{Zn}^{2+}$ & $\mathrm{Cu}^{2+}$ & $\mathrm{Si}$ & $\mathrm{Cl}^{-}$ & $\mathrm{NO}_{3}^{-}$ & $\mathrm{PO}_{4}{ }^{3-}$ & $\mathrm{SO}_{4}{ }^{2-}$ & Observations \\
\hline Wolf $^{[\leqslant 3]}$ & $\mathrm{L}^{\mathrm{a}}$ & & $\mathrm{L}^{3}$ & $L^{a}$ & & & & & & $L^{a}$ & & & & & $\begin{array}{l}\text { Woodstork } \\
\text { granite, } \\
\text { humid-tem- } \\
\text { plate }\end{array}$ \\
\hline $\begin{array}{l}\text { Harsen \& } \\
\text { Hanris }^{\text {[26] }}\end{array}$ & & & & & & & & & & & & I & $R^{b}$ & & $\begin{array}{l}\text { Laboratory } \\
\text { \& field test }\end{array}$ \\
\hline $\begin{array}{l}\text { Levin \& } \\
\text { Jackson }\end{array}$ & & & $I$ & I & & & & & & & & $\mathrm{R}$ & I & & $\begin{array}{c}\text { Laboratory } \\
\text { test }\end{array}$ \\
\hline $\begin{array}{l}\text { Zimmerman } \\
\text { et al. }{ }^{[39]}\end{array}$ & & & & & & & & & & $L^{c}$ & & $R^{d}$ & $\mathrm{R}^{e}$ & & Field test \\
\hline Lindsay ${ }^{1+0]}$ & & & & & & $\mathrm{R}$ & R & $\mathrm{R}$ & $R$ & & & I & & & $\begin{array}{l}\text { Laboratory } \\
\text { test }\end{array}$ \\
\hline Nagpal ${ }^{|+1|}$ & & $\mathrm{R}$ & & & & & & & & & & $\mathrm{I}-\mathrm{R}$ & $\mathrm{R}$ & & $\begin{array}{l}\text { Laboratory } \\
\text { \& field test }\end{array}$ \\
\hline $\begin{array}{l}\text { Botheer } \\
\text { et al. }\end{array}$ & & & & & & & & & & & & & $\mathrm{R}$ & & $\begin{array}{l}\text { Laboratory } \\
\text { test }\end{array}$ \\
\hline Driscoli $^{|+2|}$ & & & & & $\begin{array}{l}R^{f}- \\
L^{8}\end{array}$ & & & & & & & & & & $\begin{array}{c}\text { Acid forest } \\
\text { USA- } \\
\text { Canada }\end{array}$ \\
\hline Liator $^{[4+4]}$ & & & & & $\mathrm{I}^{\mathrm{h}}$ & & & & & & & $\mathrm{R}$ & $\mathrm{R}$ & & $\begin{array}{c}\text { Alpine } \\
\text { watershed } \\
\text { (Colorado) }\end{array}$ \\
\hline $\begin{array}{l}\text { Raulund-Ras- } \\
\text { mussen }{ }^{[45]}\end{array}$ & & & & $\mathrm{L}^{\mathrm{i}}$ & & & & & & & & & & $\begin{array}{l}\text { Acid soil } \\
\text { solution }\end{array}$ & \\
\hline
\end{tabular}




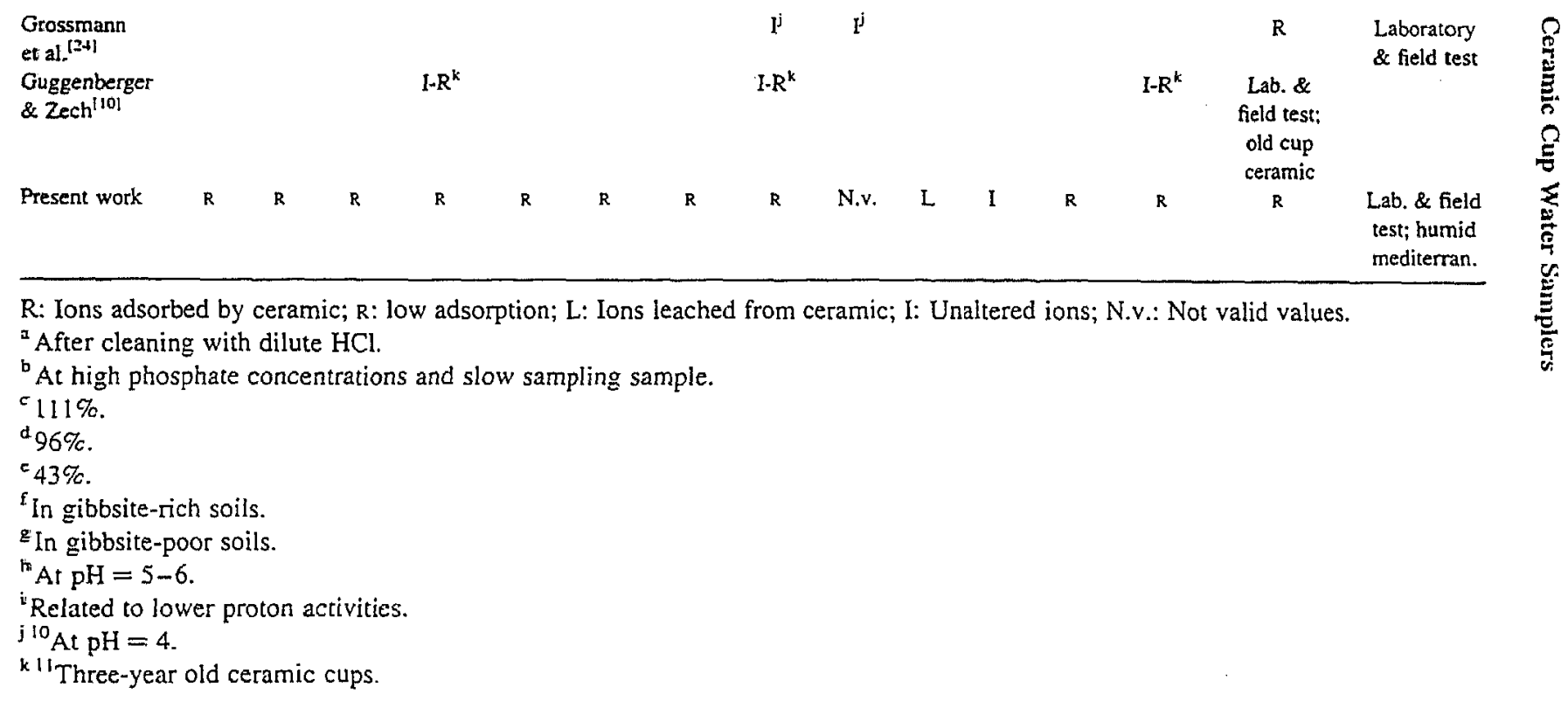


follow any clear trend and only a slight degree of sorption of $\mathrm{NO}_{3}{ }^{-}$(similar to that indicated in other research) ${ }^{[38,39,41,43]}$ and $\mathrm{SO}_{4}{ }^{2-}$ (similar to that indicated in other research $)^{[10,24]}$ was observed.

In general, with the exception of chlorides and silica (which tends to be released), almost all ions showed a tendency to be sorbed.

High sampler filling rates, induced by strong suction in the probes, also lead to at reduction in the sorption effect of ceramic cups. ${ }^{[24]}$ Consistent with this, the flow of water toward the ceramic cup was fairly high in this work (Table 2).

Two main factors ( $\mathrm{pH}$ and $\mathrm{DOC})^{[24]}$ determine the exchange capacity of ccramics. The cation exchange capacity decreases with low $\mathrm{pH}$ values because of the protonization of negative exchange sites and, to a lesser extent, the additional competition of protons for exchange sites. ${ }^{[24]}$ Thus, owing to the relative low soil pH (from 5.1 to 6.2) of the soils studied here the finding of a relatively low cation exchange capacity (resulting in a low cation release or retention) would be reasonable. Moreover, the effects of the DOC are dual. ${ }^{[24}$ First, DOC is able to form complexes with cations and hence prevents sorption and reduces the cation-filter (sorption) effect of the ceramic. Second, DOC is adsorbed by the ceramic cups, leading to an increase in their exchange capacity; and the potential sorption of cations would therefore be increased (a stronger adsorption of humic substances occurs at low $\mathrm{pH}$-values despite the effect of $\mathrm{pH}$ on the exchange capacity). We consider that this second action of DOC is a determinant factor in the adsorption behavior of the ceramic cups used in the present work: relatively low pH values (acid forest soil- solution, $\mathrm{pH}$ ranging from 5.1 to 6.2) allow the sorption of anions and DOC, which increases the exchange capacity of the cup and cation adsorption. The result is a generalized (anions, COD, and cations) ceramic cup adsorption and the inhibition of $\mathrm{H}_{4} \mathrm{SiO}_{4}$ sorption.

\section{CONCLUSIONS}

From the above results and discussion, the following conclusions can be drawn:

The time required to obtain a sample of soil solution was relatively short (mean value, $2 \mathrm{~h}$ ), the sphere of water uptake being small (with a radius from 6 to $15 \mathrm{~cm}$ ), both overall depending on the length of samplers.

Hydraulic conductivity values were not substantially modified during the sampling period (two hydrologic cycles). 
The chemical analyses obtained according to the calibration of the ceramiccups performed point to a marked adsorption of $\mathrm{PO}_{4}{ }^{3-} \mathrm{COD}$, major and minor $\left(\mathrm{Na}^{+}, \mathrm{K}^{+}, \mathrm{Ca}^{2+}, \mathrm{Mg}^{2+}, \mathrm{Fe}^{3+}, \mathrm{Al}^{3+}, \mathrm{Mn}^{2+}\right.$, and $\left.\mathrm{Zn}^{2+}\right)$, and $\mathrm{SO}_{4}{ }^{2-}$ and $\mathrm{NO}_{3}{ }^{-}$anions (except $\mathrm{Cl}^{-}$, which did not show any clear trend) tended to be adsorbed, while $\mathrm{H}_{4} \mathrm{SiO}_{4}$ was released. In any case, sorption values were relatively low and showed considerable variability. A marked sorption of phosphates hampered the validity of the values of this anion obtained in the soil-water samples.

Relatively low $\mathrm{pH}$ values $(5.1-6.2)$ favor the adsorption of anions and DOC, which increases the exchange capacity of cup and cation adsorption.

The result is a generalized tendency towards sorption (anions, COD, and cations) on the ceramic cup, excepting silica (with a competitive sorption behavior with respect to DOC), and chloride (considered an ion not strongly involved in soil sorption).

\section{ACKNOWLEDGMENTS}

The authors wish to thank the European Union (CAST/ENVIRONMENT, MEDCOP/AIR, PROTOS/TERI Programs), the Spanish fund C.I.C.Y.T. for financial support and the valuables technicians: Jesús H. Pombero, Miguel Tapia, M. Luz Cosme, Concepción Pérez, M. Cruz Macarro, and Nemesio Najac.

\section{REFERENCES}

1. Richards, L.A. A pressure-membrane extraction apparatus for soil solution. Soil Sci. 1941, 51, 377-386.

2. Zabowski, D.; Ugolini, F.C. Lysimeter and centrifuge soil solutions: seasonal differences between methods. Soil Sci. Soc. Am. J. 1990, 54, $1130-1135$.

3. Ronday, R. Centrifugation method for soil pore water assessment of the bioavailability of organic chemicals in soil. Commun. Soil Sci. Plant Anal. 1997, 28 (9\&10), 777-785.

4. Fernández, M.J.; Macías, F.; Guitián, F. Estudio comparativo de dos métodos de obtención de la solución del suelo: Aplicación al estudio de la solución de suelos podsólicos de Gallicia. Anal. Edaf. Agrob. 1980, 39 $(9 \& 10), 1587-1607$. 
5. Wagner, G.H. Use of porous ceramic cups to sample soil water within the profile. Soil Sci. 1962, 94, 386-397.

6. Long, L.F. A glass filter soil solution sampler. Soil Sci. Soc. Am. J. 1978, $42,834-835$.

7. Miller, J.D.; Herson, H.A.; Cooper, J.M.; Ferrier, R.C.; Steward, M. Evidence for enhanced atmospheric sulphate interception by Sitka spruce from evaluation of some Scottish catchment study data. Sci. Total Environ. 1991, 103, 37-46.

8. Keller, C.; Vedy, J.C. Apport de la lysimétrie sans tension pour l'étude des transferts de $\mathrm{Cu}$ et $\mathrm{C} d$ dans les sols forestiers faiblement pollués. Sci. du Sol. 1991, 29 (2), 107-124.

9. Liator, M.I. Review of soil solution samplers. Water Resour. Res. 1988, 24 (5), 727-733.

10. Guggenberger, G.; Zech, W. Sorption of dissolved organic carbon by ceramic P80 suction cups. Z. Pflanzenernähr. Bodenk. 1992,. 155, $151-155$.

11. Jemison, J.M., Jr. Fox, R.H. Estimation of zero-tension pan lysimeter collection efficiency. Soil Sci. 1992, 154 (2), 85-94.

12. Moreno, G.; Gallardo, J.F.; Ingelmo, F.; Cuadrado, S.; Hernández, J. Soil water budget in four Quercus pyrenaica forests across a rainfall gradient. Arid Soil Res. Rehabilitation 1996, 10, 65-84.

13. Schneider, K.; Turrión, M.B.; Gallardo, J.F. Modified method for measuring acid phosphatase activities in forest soils with high organic matter content. Commun. Soil Sci. Plant Anal. 2000, 31 (19\&20), 3077-3088.

14. Arribas, A.; Jiménez, E. Esquema geológico-litológico de la Provincia de Salamanca: Estudio integrado de la dehesa salmantina. C.S.I.C. Salamanca 1978, 1, 69-85.

15. Saavedra, J.; García, A.; Romero, J.; Carrión, F. Las silificaciones del valle de Amblés (inmediaciones de Avila). Bol. Geol. Minero 1985, 96, 437-443.

16. Vicente, M.A.; Molina, E.; Espejo, R. Clays in paleoweathering processes: Study of a typical weathering profile in the Hercynian basement in the Montes de Toledo (Spain). Clay Miner. 1991, 26, $81-90$.

17. Turrión, M.B.; Gallardo, J.F.; González, M.I. Extraction of soilavailable phosphate, nitrate, and sulphate ions using ion exchange membranes and determination by ion exchange chromatography Commun. Soil Sci. Plant Anal. 1999, 30 (7\&8), 1137-1152. 
18. Gallardo, J.F.; Sánchez, M.; Saavedra, J.; García, A. Características de los suelos forestales de la Sierra de Gata. Studia Oecol. 1980, I. 241-264.

19. F.A.O., World Reference Base for Soil Resources; F.A.O.: Rome, Italy, 1998; 88.

20. Soilmoisture. Booklet of Porous Ceramics by Soilmoisture, Series 600; Soilmoisture Equipment Corp.: Santa Barbara, CA, 1989; 19.

21. Alberts, E.E.; Burwell, R.E.; Schuman, G.E. Soil nitrate-nitrogen determined by coring and solution extraction techniques. Soil Sci. Soc. Am. J. 1977, 41, 90-92.

22. Haines, B.L.; Waide, J.B.; Todd, R.L. Soil solution nutrient concentrations sampled with tension and zero-tension lysimeters: Report of discrepancies. Soil Sci. Soc. Am. J. 1982, 46, 658-661.

23. Ranson, M.D.; Smeck, N.E. Water table characteristics and water chemistry of seasonal wet soils of southwestern Ohio. Soil Sci. Soc. Am. J. 1986, 50, 1281-1289.

24. Grossmann, J.; Bredemeier, M.; Udluft, P. Sorption of trace metals by suction cups of aluminium oxide, ceramic and plastics. Z. Pflanzenernähr. Bodenk. 1990, 153, 359-364.

25. Hendershot, W.H.; Courchesne, F. Comparsion of soil solution chemistry in zero tension and ceramic-cup tension lysimeters. J. Soil Sci. 1991, 42, 577-583.

26. Hansen, E.A.; Harris, A.R. Validity of soil-water samples collected with porous ceramic cups. Soil Sci. Soc. Am. J. 1975, 39, 528-536.

27. Bottcher, A.B.; Miller, L.W.; Campbell, K.L. Phosphorous adsorption in various soil-water extraction cup nuaterials: Effect of acid wash. Soil Sci. 1984, 137 (4), 239-244.

28. Barbee, G.C.; Brown, K.W. Comparison between suction and freedrainage soil solution samplers. Soil Sci. 1986, 141(2), 149-154.

29. American Public Health Association, Standard Methods for Examination of Water and Wastewater; APHA-AWWH-WPCF: Washington, DC, 1980; 1134.

30. Menéndez, I.; Moreno, G.; Gallardo, J.F. Soil solution composition in forest soils of "Sierra de Gata" Mountains Central-Western Spain: relationship with soil water content. Arid Soil Res. Rehabilitation 1995, 9, 495-502.

31. Moreno, G.; Gallardo, J.F.; Schneider, K.; Ingelmo, F. Water and bioelement fluxes in four Quercus pyrenaica forests along a pluviometric gradjent. Ann. For. Sci. 1996, 53, 625-639.

32. Talsma, T.; Hallam, P.M.; Mansell, R.S. Evaluation of porous cup soilwater extractors. phvsical factors. Aust. J. Soil Res. 1979, 17, 417-422. 
33. Wu, L.; Baker, J.M.; Allmaras, R.R. Numerical and field evaluation of soil water sampled by suction lysimeters. J. Environ. Qual. 1995, 24, 147-152.

34. Morrison, R.D.; Lowery, B. Effect of cup properties, sampler geometry and vacuum on the sampling rate of porous cup samplers. Soil Sci. 1990, $149(5), 308-316$.

35. Naraismhan, T.N.; Dreiss, S.J. A numerical technique for modelling transient flow of water to a soil water sampler. Soil Sci. 1986, 141 (3), 230-236.

36. Cochran, P.H.; Marison, G.M.; Leaf, A.L. Variation in tension lysimeter leachate volumes. Soil Sci. Soc. Am. J. 1970, 34, 309-311.

37. Valente, J.F.; Dynia, J.F. Uso de cápsulas porosas para extrair soluçao do solo. Pesq. Agropec. Bras, Brasília 1990, 25 (10), 1523-1528.

38. Levin, M.J.; Jackson, D.R. A comparison of in site extracts for sampling soil water. Soil Sci. Soc. Am. J. 1977, 41, 535-536.

39. Zimmerman, C.F.; Price, M.T.; Montgomery, R.J. A comparisòn of ceramic and Teflon in situ samplers for nutrient pore water determinations. Estuarine Coastal Mar. Sci. 1978, 7, 93-97.

40. Lindsay, W.L. Solid phase: Solution equilibria in soils. Chemistry in the Soil Environment; American Society of Agronomy: Madison, WI, 1981; 183-202.

41. Nagpal, N.K. Comparison among and evaluation of ceramic porous cup soil water samplers for nutrient transport studies. Can. J. Soil Sci. 1982, 62, 685-694.

42. Driscoll, C.T.; Van Breeman, N.; Mulder, J. Aluminum chemistry on a forested spodosol. Soil Sci. Soc. Am. J. 1985, 49, 437-444.

43. Wolff, R.G. Weathering woodstock granite, near Baltimore, Maryland. Am. J. Sci. 1967, 265, 106-117.

44. Liator, M.I. Aluminum chemistry: Fractionation, speciation and mineral equilibria of soil interstitial waters of an alpine watershed, Front Range Colorado. Geochim. Cosmochim. Acta 1987, 51, 1285-1295.

45. Raulund-Rasmussen, $\mathrm{K}$. Aluminium contamination and other changes of acid soil solution isolated by means of porcelain suction-cups. J. Soil Sci. 1989, 40, 95-101.

46. Harter, R.D.; Naidu, R. Review and analysis. An assessment of environmental and solution parameter impact on trace-metal sorption by soils. Soil Sci. Soc. Am. J. 2001, 65, 597-612.

47. Gallardo, J.; Sánchez, M.; Saavedra, J.; García, A. Influencia de la materia orgánica en la génesis de gibbsita y caolinita en suelos graníticos del Centro-Oeste de España. Clay Miner. 1976, 11, 241-249. 
48. Bronevoy, V.A.; Kopeykin, V.A.; Tenyakov, V.A. Main parageneses of bauxite-bearing weathered mantle and some aspects of bauxitization theory. Doklady Akad. Nauk SSSR 1975, 225, 158-161.

49. Wood, A.L.; Wilson, J.T.; Cosby, R.L.; Hornsby, A.G.; Baskin, L.B. Apparatus and procedure for sampling soil profiles for volatile organic compounds. Soil Sci. Soc. Am. J. 1981, 45, 442-444.

50. Suárez, D.L. Prediction of $\mathrm{pH}$ errors in soil; water extractors due to degassing. Soil. Sci. Soc. Am. J. 1987, 51, 64-67.

51. Hetzel, F.; McColl, J.G. Silicon, aluminum, and oxalic acid interactions in two California forest soils. Commun. Siol Sci. Plant Anal. 1997, 28 (13\&14), 1209-1222. 